\title{
Volume calculation and analysis of the changes in moraine-dammed lakes in the north Himalaya: a case study of Longbasaba lake
}

\author{
Xiaojun YAO, ${ }^{1,2}$ Shiyin LIU, ${ }^{1}$ Meiping SUN,,${ }^{1}$ Junfeng WEI, ${ }^{1}$ Wanqin GUO ${ }^{1}$ \\ ${ }^{1}$ State Key Laboratory of Cryosphere Sciences, Cold and Arid Regions Environmental and Engineering Research Institute, \\ Chinese Academy of Sciences, Lanzhou, China \\ E-mail: yaoxj_nwnu@163.com \\ ${ }^{2}$ Geography and Environment College, Northwest Normal University, Lanzhou, China
}

\begin{abstract}
Glacial lake outburst flood hazards in the Himalayan region have received considerable attention in recent years. Accurate volume estimation for glacial lakes is important for calculating outburst flood peak discharge and simulating flood evolution. Longbasaba lake, a potentially dangerous moraine-dammed lake, is located on the north side of the Himalaya. Its depth was surveyed using the SyQwest Hydrobox ${ }^{\mathrm{TM}}$ high-resolution echo sounder, and 6916 measurements were collected in September 2009. The maximum and average depths of the lake were $102 \pm 2$ and $48 \pm 2 \mathrm{~m}$, respectively. The morphology of the lake basin was modeled by constructing a triangulated irregular network, and the lake was found to have a storage capacity of $0.064 \pm 0.002 \mathbf{~ k m}^{3}$. Multi-source remote-sensing images from Landsat MSS, Landsat TM/ETM+ and Terra ASTER and a topographic map were digitized to delineate the outlines of the lake between 1977 and 2009. The results indicate that the length and area of the lake have increased during the past 32 years, with a drastic expansion occurring since 2000. Based on volume and area data of Longbasaba lake in different periods, we deduced an empirical equation of the lake volume-area relationship that can be used to calculate the storage capacity of similar moraine-dammed lakes in the Himalayan region.
\end{abstract}

\section{INTRODUCTION}

Glacial lakes are indicators of climate change because their expansion or contraction reflects variations of water balance and heat condition in mountains (Shi and Ren, 1990). In the Himalaya, a number of glacial lakes, of which morainedammed lakes are the most common type, have recently appeared and expanded in and around alpine glaciers (Che and others, 2004; Chen and others, 2005; Lu and others, 2005; Komori, 2008; Sharma and others, 2009; Gardelle and others, 2011). These expanding glacial lakes are often surrounded by steep slopes and contained by fragile moraines that are prone to failure. Devastating events (e.g. rockfalls, glacier calving and avalanches into the lake area) can create large waves and trigger flooding due to washout (Awal and others, 2010). In the past 50 years, >35 large glacial lake outburst floods (GLOFs) have taken place in the Himalayan region, many of which caused great damage not only to the local catchment but also to the surrounding lowlands far beyond the limits of the lake area (Xu and Feng, 1989; Clague and Evans, 2000; Carrivick, 2010; Shrestha and others, 2010). Meanwhile, small-scale GLOFs occur almost every year, usually going unnoticed because of the limited damage caused or because of their remote location (ICIMOD, 2007). GLOFs and related debris flows play a dominant role in mountain disasters in the Himalaya (e.g. Xu and Feng, 1989; Ding and Liu, 1992; Fujita and others, 2008; Bajracharya and Mool, 2009). Numerous studies have confirmed that temperature increase in the Himalayan region has been greater than in other areas at the same latitude (Zheng and others, 2002; Singh and Bengtsson, 2005; Li and others, 2011), and the rate of warming has been almost twice the rate of global warming since the $1950 \mathrm{~s}\left(0.23\right.$ vs $0.13^{\circ} \mathrm{C}$ per decade) (Yang and others, 2006). During recent decades, glaciers in this region, as in many other regions worldwide, have experienced accelerated recession (Pu and others, 2004; Zhang and others, 2010). Given rapid warming and glacier retreat, it is anticipated that glacial lakes will continue to expand into the areas between receding glacier fronts and terminal moraines, and that GLOFs will become more frequent (Richardson and Reynolds, 2000; Haeberli and others, 2004; Yao and others, 2010). We therefore need improved monitoring of morainedammed lakes and a better understanding of GLOF mechanisms (Reynolds, 1998; He and others, 2002; Chen and others, 2007; Wang and Liu, 2007).

Accurate estimation of the storage capacity of morainedammed lakes is essential for predicting flood peak discharge, simulating flood evolution and establishing early warning systems (Bajracharya and others, 2007; Ng and others, 2007). As suggested by previous studies (Chen and others, 2008; Fujita and others, 2008), the volume of moraine-dammed lakes can be estimated from digital elevation models (DEMs) using reservoir capacity methods based on a grid, cross sections or contours. The volume of Telamukanli lake in the upper stream of Yarkant river, for example, was calculated using a cross-section method in a field study in 1987 (Shi and others, 1991). In addition, Evans (1986) and Huggel and others (2002) proposed an empirical relationship between glacial lake volume and area. For the moraine-dammed lakes in the Himalayan region, due to their harsh climate and remoteness, there is often a shortage of ground-based monitoring data, especially lake water depth (Wang and others, 2010). So far, in situ measurements of lake water depth have only been conducted at a few glacial lakes on the south side of the Himalaya (Bhargava, 1995; Yamada, 1998; Mool and others, 2001; Sakai and others, 2005). They have not yet been carried out on the north side, so there is 


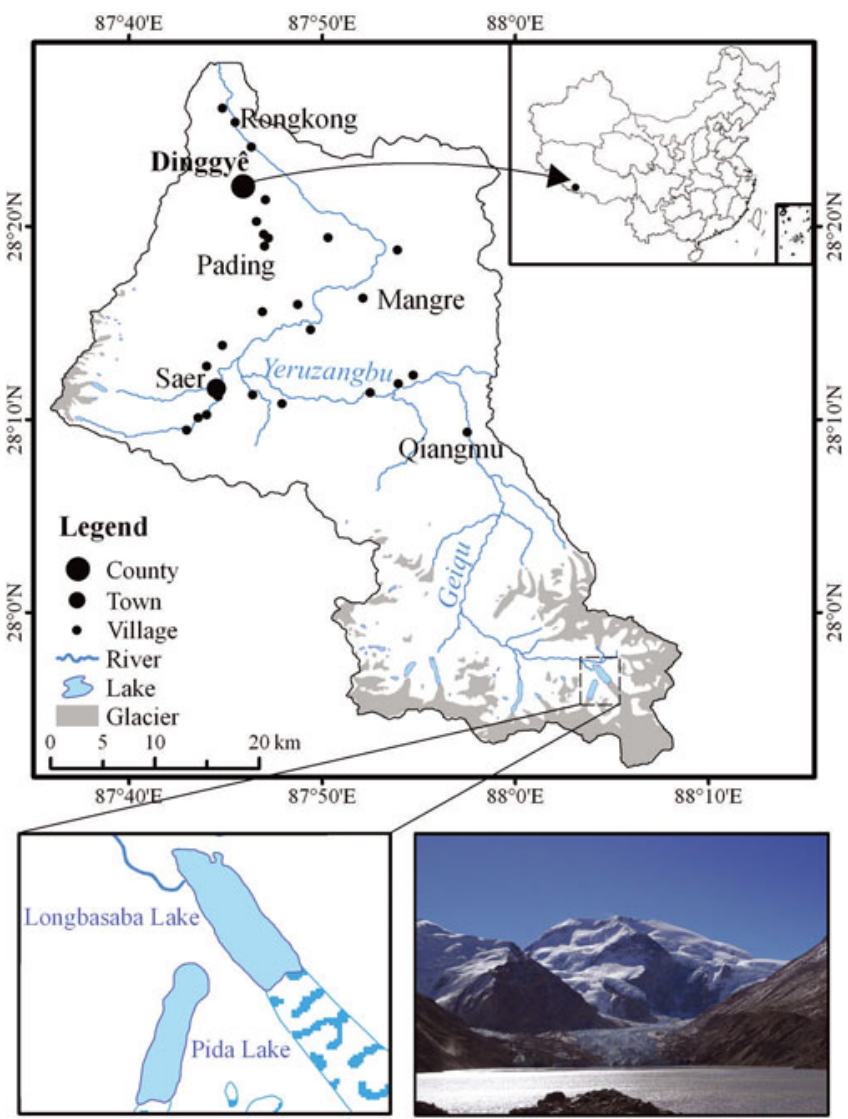

Fig. 1. Location of Longbasaba lake, the potentially GLOF-affected region and its status. (Photo taken from dam by Yao.)

little knowledge of the morphology and storage capacity of moraine-dammed lakes in this region.

In this study, we first report the results of in situ surveys conducted in September 2009 on Longbasaba lake in Dinggyê County, Tibet. Based on the water depth data collected by the SyQwest Hydrobox ${ }^{\mathrm{TM}}$ portable highresolution shallow-water echo sounder, we model the morphology of the lake basin by constructing a triangulated irregular network (TIN), and calculate its volume. By interpreting multi-source remote-sensing images, we also analyze the history of Longbasaba lake. Finally, we propose an empirical formula for the volume-area relationship of Longbasaba lake by assuming that the lake basin is in steady state.

\section{STUDY AREA}

Longbasaba lake $\left(27^{\circ} 57^{\prime} 17^{\prime \prime} \mathrm{N}, 88^{\circ} 04^{\prime} 55^{\prime \prime} \mathrm{E}\right)$ is located at the headwaters of the Geiqu river, a tributary of the Yeruzangbu river in the Pumqu river watershed. Its altitude was $5499 \mathrm{~m}$ a.s.I. in 2009, with a length of $2210 \mathrm{~m}$ from north to south and a width of $685 \mathrm{~m}$ from east to west. The lake is dammed by an end moraine formed by modern glaciation (Fig. 1). On the southwest side of Longbasaba lake, there is another moraine-dammed lake, Pida lake, at $5564 \mathrm{ma.s.l}$. The distance between the two lakes is $\sim 335 \mathrm{~m}$. The recharge of Longbasaba lake has two main sources: glacier meltwater and precipitation. The terminus of Longbasaba glacier, with abundant crevasses, stretches into the lake in the southeastern corner. Many serac clusters and small supraglacial lakes develop on the glacier. Ice floes of various sizes from glacier disintegration float on the lake.

According to observations by the local water conservation office, Longbasaba lake grew rapidly in 2004, putting its dam at risk of failure (Li and Zhang, 2008; Wang and others, 2008). A hazard investigation report on the lake issued by the Hydrological Department of the Tibet Autonomous Region in 2006 pointed out that a flood would threaten the towns of Saer and Jiangga, where Dinggyê County center was located, along with 23 other downstream villages, and would destroy roads, bridges and communication facilities between the city of Shigatse and Dinggyê County and the Rongkong hydropower station. Hence, there is an urgent need to monitor the variations in Longbasaba lake.

\section{DATA AND METHODS}

\section{In situ survey data}

In September 2009, extensive in situ surveys of the water depth of Longbasaba lake were conducted using the SyQwest Hydrobox ${ }^{\mathrm{TM}}$ portable high-resolution shallowwater echo sounder. This instrument is designed exclusively for inshore and coastal hydrographic marine surveys in water depths of $800 \mathrm{~m}$. The measuring system consists of a laptop computer, an echo sounder, an eTrex Vista ${ }^{\mathrm{TM}}$ GPS receiver and a powered rubber dinghy. As shown in Figure 2,
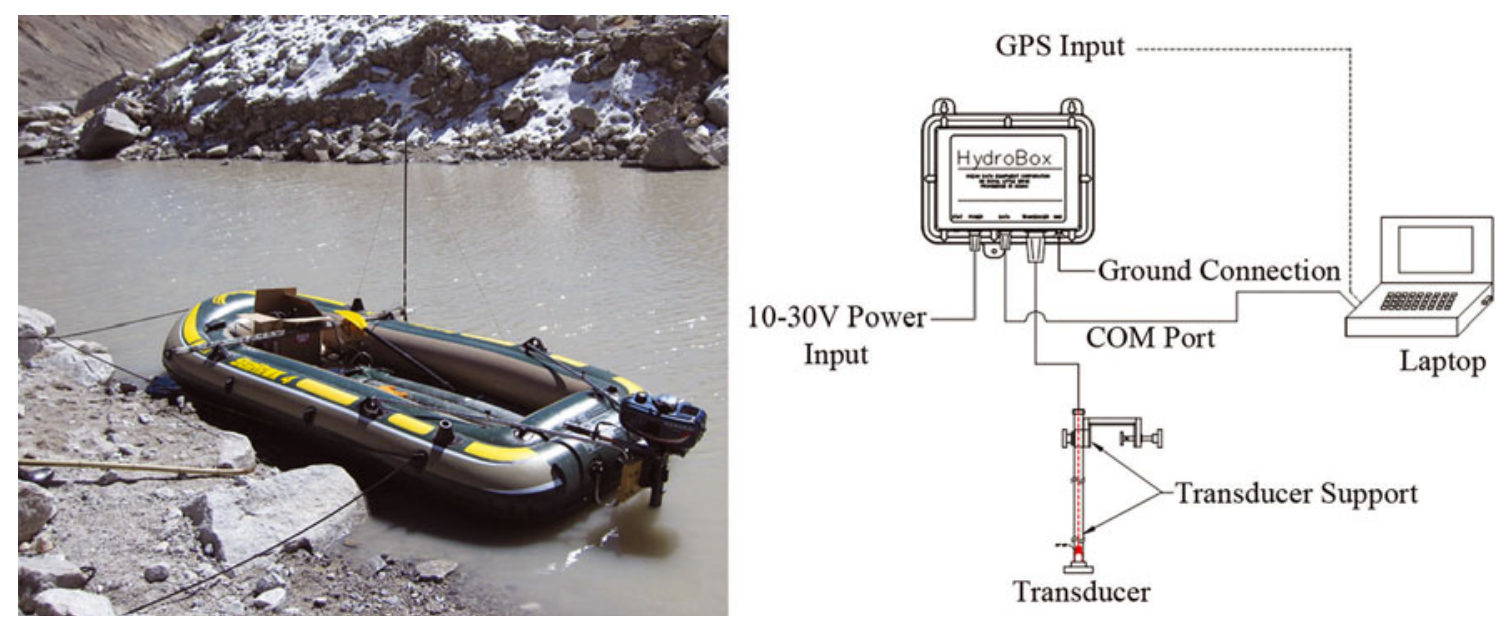

Fig. 2. The rubber dinghy used in the field investigation, and schematic of measuring system. 


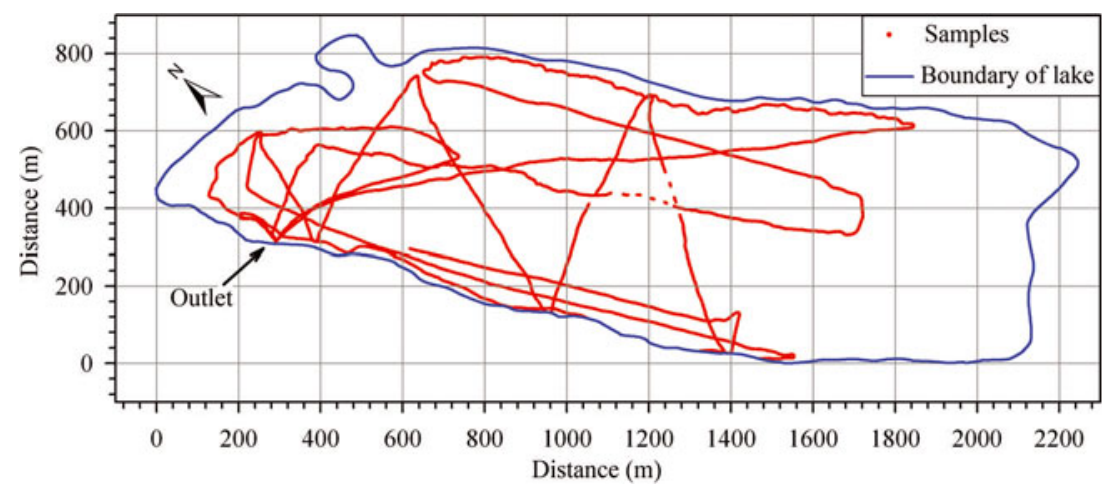

Fig. 3. The distribution of sampling points (red circles) of the sonar system. The blue line is the lake boundary derived from Landsat TM in November 2009.

the echo sounder was installed on the right side of the head of the rubber dinghy, to reduce as far as possible disturbance to the transducer from bubbles produced by the propeller. As the rubber dinghy moved, we continually examined water depth values displayed on the laptop screen to ensure that the transducer was completely submerged and its radiant surface was parallel to the water surface. The sonar system's position was acquired with the eTrex Vista GPS receiver, with a horizontal precision of about $3-6 \mathrm{~m}$. The GPS receiver was installed on top of the transducer support to ensure that its location was consistent with the measuring point. The course of the rubber dinghy was set to give a uniform distribution of measuring points, with first measurements along the lake boundary. To ensure the transducer was always submerged in water and to prevent the transducer and propeller from hitting rocks under the surface, a distance of at least 2-5 m was always maintained between the rubber dinghy and the lake bank. The rubber dinghy moved in a zigzag pattern along the minor axis of the lake and a U-shape course along the major axis, with a total of 35558 measurement points collected (Fig. 3). Due to frequent collapses of ice bodies and the resulting huge waves, we did not measure the inaccessible parts near the glacier terminus. Furthermore, to verify the accuracy of the sonar depth data, 33 random points were measured using a measuring rope. The estimated mean error was $1-2 \mathrm{~m}$, so the sonar data were considered to be highly accurate.

\section{Remote-sensing image and topographic map}

During the fieldwork, large amounts of gravel and rocks fell into the lake from the steep flanks, which hindered spatial data collection along the lake boundary. In fact, our rubber dinghy was once damaged by falling rocks. As an alternative data collection method, we downloaded a Landsat Thematic Mapper (TM) image (path 139, row 41) acquired on 9 November 2009 from the United States Geological Survey (USGS) website (http://glovis.usgs.gov) as a reference. From the same website we also downloaded other remote-sensing images of Longbasaba lake: one Landsat Multispectral Scanner (MSS) image, three Landsat TM images and five Landsat Enhanced TM Plus (ETM+) images. Four Advanced Spaceborne Thermal Emission and Reflection Radiometer (ASTER) images were bought from USGS. We also used a topographic map, dated 1980, at a scale of $1: 50000$. Details of these images are shown in Table 1. Remote-sensing images concentrated mainly on November and December, as well as May and January when the lake was frozen.
All Landsat images listed in Table 1 were registered digitally to the 2009 Landsat TM scene (which is used as the 'base') using a cubic polynomial model in ENVI software, by selecting 10-15 ground-control points that were clearly identifiable in both images, with most of the points chosen on stable terrain adjacent to Longbasaba lake. The registration error was 0.8 pixel $(23 \mathrm{~m})$ when registering the MSS image to the TM image, and 0.5 pixel $(14 \mathrm{~m})$ when registering the TM/ETM+ image to the TM image. The topographic map was scanned at $300 \mathrm{dpi}$ and spatially referenced to the TM image using the thin-plate spline model. Contours on the topographic map were then delineated to interpolate the DEM, which was used in the process of Terra ASTER image orthorectification. Similarly, Terra ASTER images were referenced to the 2009 TM base image, with a registration accuracy of 0.5 pixel, or $14 \mathrm{~m}$. After this pre-processing, the Longbasaba lake boundary in different years was digitized and geometric parameters such as area and length were calculated in ArcGIS software.

Error in the lake extent from remote-sensing image interpretation was controlled by the image resolution and co-registration error (Hall and others, 2003). From Williams

Table 1. Topographic map and satellite remote-sensing data

\begin{tabular}{|c|c|c|c|}
\hline Date & $\begin{array}{l}\text { Satellite sensor/ } \\
\text { map }\end{array}$ & $\begin{array}{l}\text { Spatial resolution/ } \\
\text { map scale }\end{array}$ & Source \\
\hline 23 Jan 1977 & Landsat MSS & $57 \mathrm{~m}$ & USGS/NASA \\
\hline Nov 1980 & Topographic map & $1: 50000$ & $\begin{array}{l}\text { Chinese military } \\
\text { geodetic service }\end{array}$ \\
\hline 10 Nov 1989 & Landsat TM & $28.5 \mathrm{~m}$ & USGS/NASA \\
\hline 13 Jan 1990 & Landsat TM & $28.5 \mathrm{~m}$ & USGS/NASA \\
\hline 6 Nov 1999 & Landsat ETM+ & $28.5 \mathrm{~m}$ & USGS/NASA \\
\hline 26 Dec 2000 & Landsat ETM+ & $28.5 \mathrm{~m}$ & USGS/NASA \\
\hline 13 Dec 2001 & Landsat ETM+ & $28.5 \mathrm{~m}$ & USGS/NASA \\
\hline 13 May 2002 & Terra ASTER & $15 \mathrm{~m}$ & NASA/METI \\
\hline 3 Dec 2003 & Landsat ETM+ & $28.5 \mathrm{~m}$ & USGS/NASA \\
\hline 5 Dec 2004 & Terra ASTER & $15 \mathrm{~m}$ & NASA/METI \\
\hline 30 May 2005 & Terra ASTER & $15 \mathrm{~m}$ & NASA/METI \\
\hline 17 Nov 2006 & Landsat TM5 & $28.5 \mathrm{~m}$ & USGS/NASA \\
\hline 30 Dec 2007 & Terra ASTER & $15 \mathrm{~m}$ & NASA/METI \\
\hline 30 Nov 2008 & Landsat ETM+ & $28.5 \mathrm{~m}$ & USGS/NASA \\
\hline 9 Nov 2009 & Landsat ETM+ & $28.5 \mathrm{~m}$ & USGS/NASA \\
\hline
\end{tabular}

Note: METI is Ministry of Economy, Trade and Industry, Japan. 


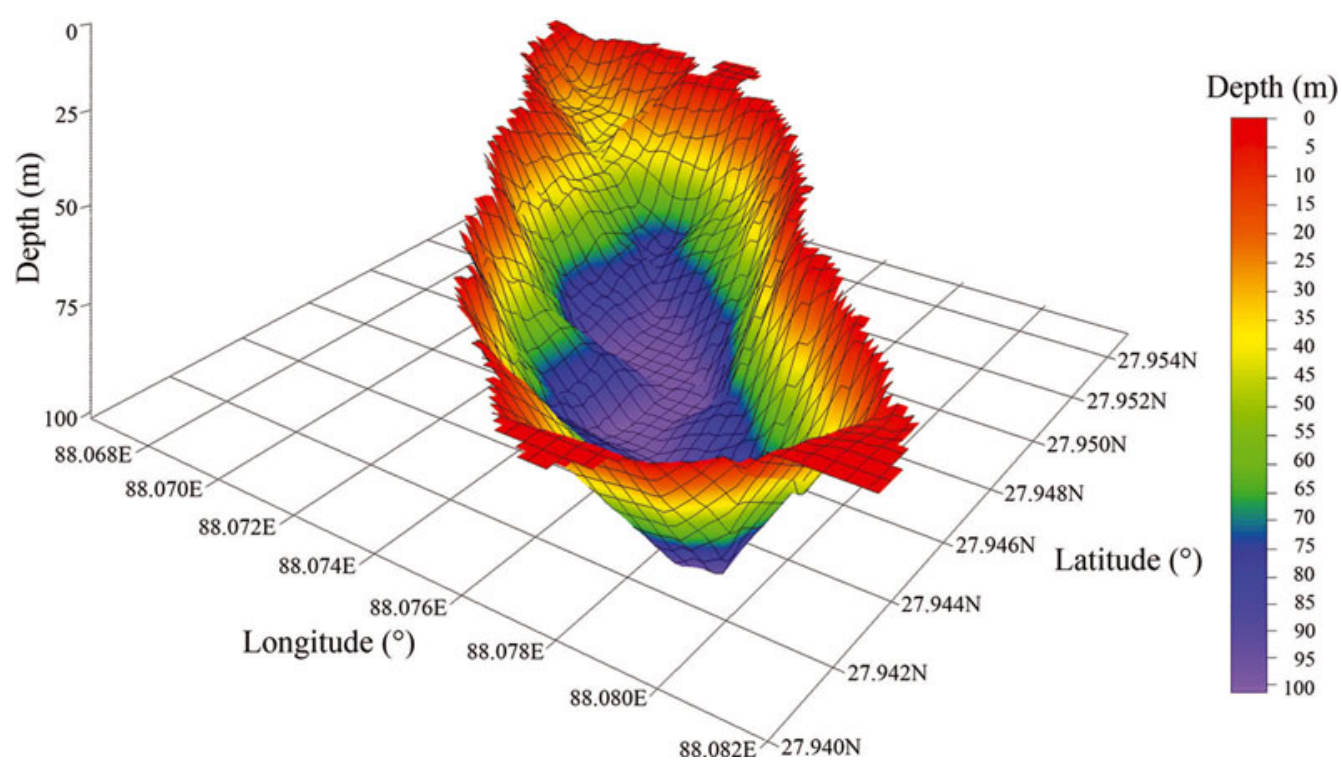

Fig. 4. Morphology modeling of Longbasaba lake in 2009 (viewing angle is from south to north).

and others (1997):

$$
d=\sqrt{\sum_{1}^{n} \lambda^{2}}+\sqrt{\sum_{1}^{n} \varepsilon^{2}}
$$

where $d$ is the linear dimension error, $\lambda$ is the original pixel resolution of each image $(28.5 \mathrm{~m}$ for TM or ETM+ data, $15 \mathrm{~m}$ for ASTER data and $57 \mathrm{~m}$ for MSS data) and $\varepsilon$ is the registration error. Thus the accuracy is actually $\pm 54 \mathrm{~m}$ for Landsat TM and Landsat ETM+ data, $\pm 35 \mathrm{~m}$ for Terra ASTER data and $\pm 103 \mathrm{~m}$ for Landsat MSS data.

Changes in the areal extent of Longbasaba lake were measured with an accuracy of $\pm 0.0023 \mathrm{~km}^{2}$ for Landsat TM and ETM+ images, $\pm 0.0092 \mathrm{~km}^{2}$ for the Landsat MSS image and $\pm 0.0006 \mathrm{~km}^{2}$ for the Terra ASTER images, with error, a, in the area given by (Hall and others, 2003)

$$
a=A(2 d / \pi)
$$

where $A=\lambda^{2}$ and $d$ is the error in the linear dimension from Eqn (1).

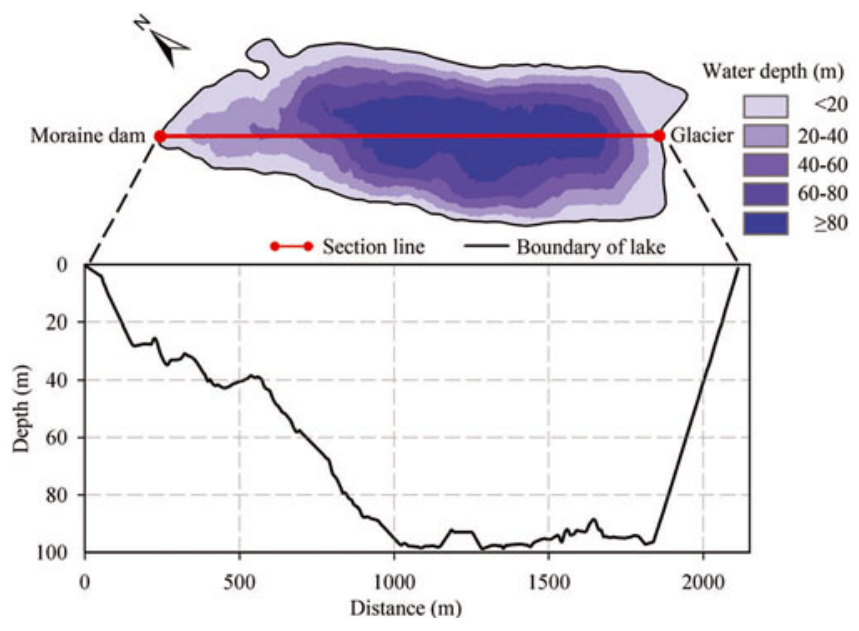

Fig. 5. Profile map of Longbasaba lake water depth from the moraine dam to the glacier terminus in 2009.

\section{Data processing}

In total, 6916 discrete measurement points were obtained. The maximum depth measured was $102 \pm 2 \mathrm{~m}$, and the average depth was $48 \pm 2 \mathrm{~m}$. This is $18 \pm 2 \mathrm{~m}$ deeper than measured by Liu and Sharmal (1988), who found an average depth of $30 \mathrm{~m}$ during their expedition to the glacier lakes in the Pumqu (Arun) and Poiqu (Bhote-Sun Kosi) river basins.

Three-dimensional coordinate data $(x, y$, depth) of the 6916 discrete points and vector data of the lake boundary were processed using ArcGIS software. The elevation of each point in the lake basin was calculated from the difference between the altitude of the water surface, obtained by GPS, and the depth value obtained by the sonar system. A TIN was built using the ArcGIS 3-D Analyst Module. The digitized boundary of Longbasaba lake derived from the Landsat TM image of 2009 was a constraint on the TIN boundary, with the depth assumed to be zero. Based on the assumptions that (1) the lake basin is in steady state, (2) the part of the lake basin outside the vectorized boundary line for a given year is filled by the glacier, and (3) the water level does not change, the volumes of Longbasaba lake in different years were then calculated using a GIS overlay analysis.

\section{RESULTS AND DISCUSSION}

\section{Morphology modeling of Longbasaba lake}

Based on the TIN data, the basin morphology of Longbasaba lake was modeled as indicated in Figure 4. It is apparent that the basin bottom of the lake is relatively flat and its flanks are steep, with slopes ranging from $28^{\circ}$ to $30^{\circ}$. The southeastern side is steeper than the northwestern side. From the water depth profile it is seen that the depth slowly increases from moraine dam to glacier terminus in the frontal $550 \mathrm{~m}$, then suddenly drops to reach the bottom of the lake. The depth varied from 86 to $101 \mathrm{~m}$ at a distance of 1000-1850 $\mathrm{m}$ from the moraine dam (Fig. 5). As there are no measurements at the junction of the lake and the glacier terminus, changes in depth were represented as a linear decrease in this area, due to the assumption of zero water depth at the lake boundary. 


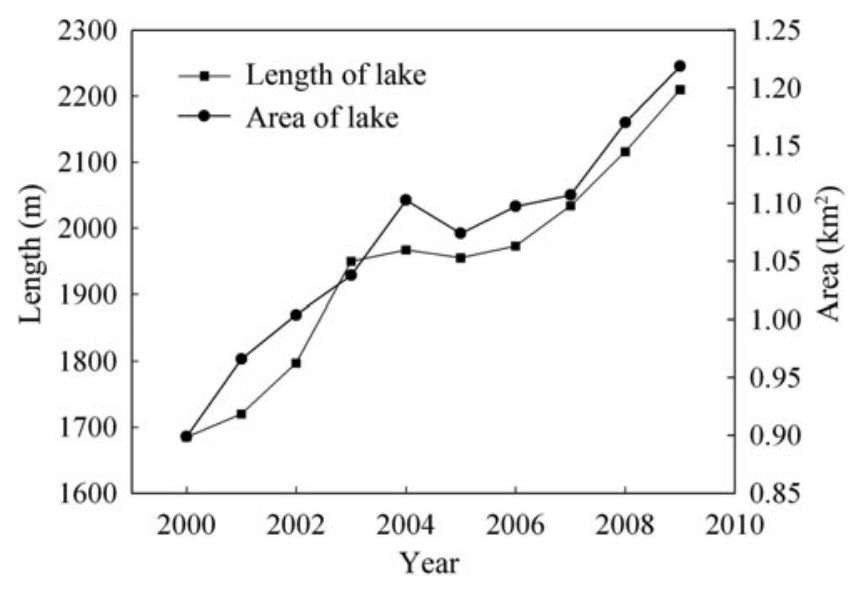

Fig. 6. Changes in the length and area of Longbasaba lake from 2000 to 2009.

\section{Spatio-temporal changes of Longbasaba lake}

Results of the remote-sensing investigation suggest that the length and area of Longbasaba lake have increased over the past 32 years. In 1977, the length and area were $946 \pm 103 \mathrm{~m}$ and $0.3320 \pm 0.0092 \mathrm{~km}^{2}$, respectively. By 2009 these values had increased to $2210 \pm 54 \mathrm{~m}$ and $1.2187 \pm 0.0023 \mathrm{~km}^{2}$. This represents proportional changes in length and area of $137 \pm 32 \%$ and $267 \pm 11 \%$. During the study period, the average annual changes were $39.50 \pm 5 \mathrm{~m} \mathrm{a}^{-1}$ and $0.0281 \pm 0.0004 \mathrm{~km}^{2} \mathrm{a}^{-1}$. Over the period 2000-09, these changes reached $58 \pm 6 \mathrm{~m} \mathrm{a}^{-1}$ and $0.0355 \pm 0.0003 \mathrm{~km}^{2} \mathrm{a}^{-1}$, about three times and twice as high, respectively, as the values over the period 1977-80. As can be seen from Figure 6, the variations in length and area during 2000-09 can be divided into three phases:

1. 2000-04: the lake was in a state of rapid expansion. Its length and area increased by $282 \pm 45 \mathrm{~m}$ and $0.2041 \pm 0.0003 \mathrm{~km}^{2}$, at rates of $71 \pm 22 \mathrm{~m} \mathrm{a}^{-1}$ and $0.0510 \pm 0.0001 \mathrm{~km}^{2} \mathrm{a}^{-1}$, respectively. The total proportional changes were $16.74 \pm 3 \%$ and $22.71 \pm 0.68 \%$. This finding corresponds well with the result reported by the local water resource department ( $\mathrm{Li}$ and Zhang, 2008; Wang and others, 2008).

2. 2005-07: the lake was in relatively steady state. In 2005, its length was $1955 \pm 35 \mathrm{~m}$, slightly less than in 2004 . Its area decreased accordingly, from $1.1029 \pm 0.0006 \mathrm{~km}^{2}$ to $1.0739 \pm 0.0006 \mathrm{~km}^{2}$. This change was probably the result of the drainage measures conducted by the Department of Water Resources of Tibet Autonomous Region in 2005 ( $\mathrm{Li}$ and Zhang, 2008). In the following 2 years, the lake expanded again, but at a slower rate than during the first phase. Until 2007, its area was about the same as in 2004 .

3. 2008-09: the lake was again in a state of a rapid growth. The length and area rapidly increased, and the average annual changes amounted to $94 \pm 54 \mathrm{ma}^{-1}$ and $0.0488 \pm 0.0023 \mathrm{~km}^{2} \mathrm{a}^{-1}$, respectively, almost equivalent to those observed during the first period.

Figure 7 presents the spatial changes of the lake boundary. There is a clear trend that the lake grew as the glacier retreated. Many other Himalayan moraine-dammed lakes

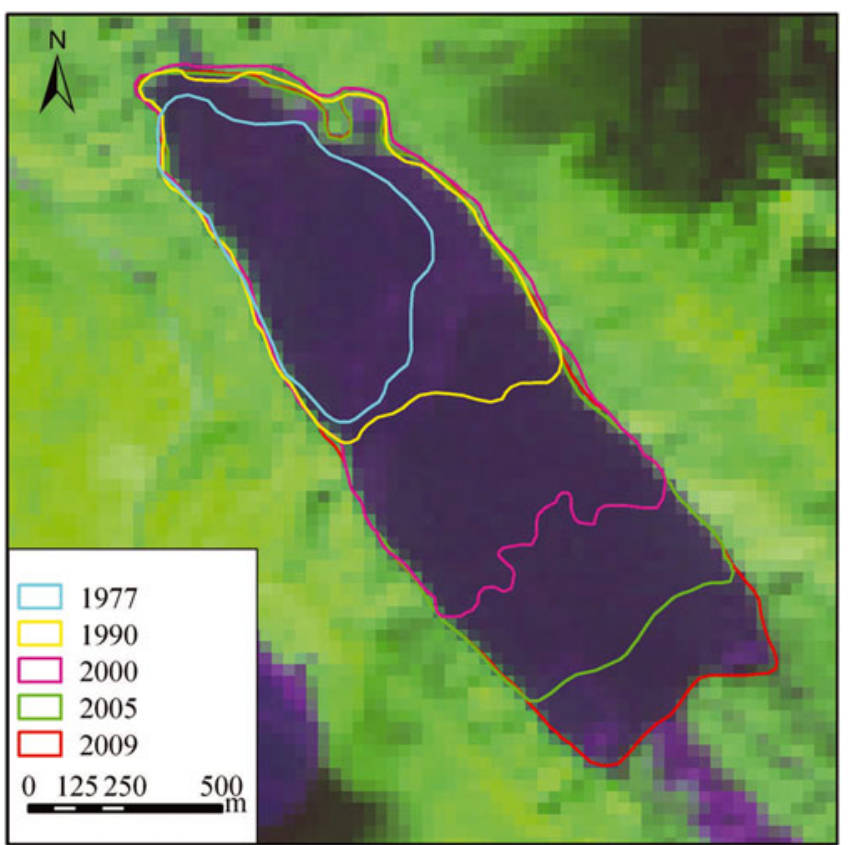

Fig. 7. Spatial variation of Longbasaba lake from 1977 to 2009 (composition of spectral bands of Landsat TM is 4,5,3).

have been expanding as their associated glacier retreats (e.g. Tsho Rolpa, Imja and Luggye Tsho) (Richardson and Reynolds, 2000). It should be noted that the underside of the glacial cliff at the terminus of Longbasaba glacier has a concave shape, easily resulting in frequent collapses of ice bodies due to the calving process (Benn and others, 2007; Sakai and others, 2009; Otero and others, 2010). Once a huge amount of ice avalanches into the lake, it will cause a rapid rise in water level. However, there is to date no detailed information at the glacier/lake interface.

\section{Volume estimation of Longbasaba lake}

The volume of a lake can be interpreted as the water volume between the surface and a datum surface of the lake basin (Shi and others, 1991). The volume of Longbasaba lake, $0.064 \pm 0.002 \mathrm{~km}^{3}$ in 2009 , was calculated using the surface elevation and the lake bed derived from the TIN. Note that the water depth near the glacier terminus was assumed to be zero in the morphology modeling, which probably leads to the actual volume of Longbasaba lake being underestimated. However, our calculation provides an approximate estimate of the magnitude of this moraine-dammed lake.

For the relationship between the lake volume and area, Huggel and others (2004) have proposed an empirical formula based on a study of glacial lakes in North America, South America, Iceland and the Alps. When using this formula to estimate the volume of larger moraine-dammed lakes in the Himalayan region, there are obvious inconsistencies with the measured values. We therefore attempt to build an empirical formula of volume and area suitable for the investigated region. By comparing water depths at Imja lake on the south slope of the Himalaya obtained in 1992 and 2002 (Yamada, 1998; Sakai and others, 2005), it was found that the morphology of the lake basin showed little change while the area changed substantially. We assume that the water level remains constant and calculate the storage capacity of Longbasaba lake in different years from vector data of the lake boundary. As shown in Figure 8, the 


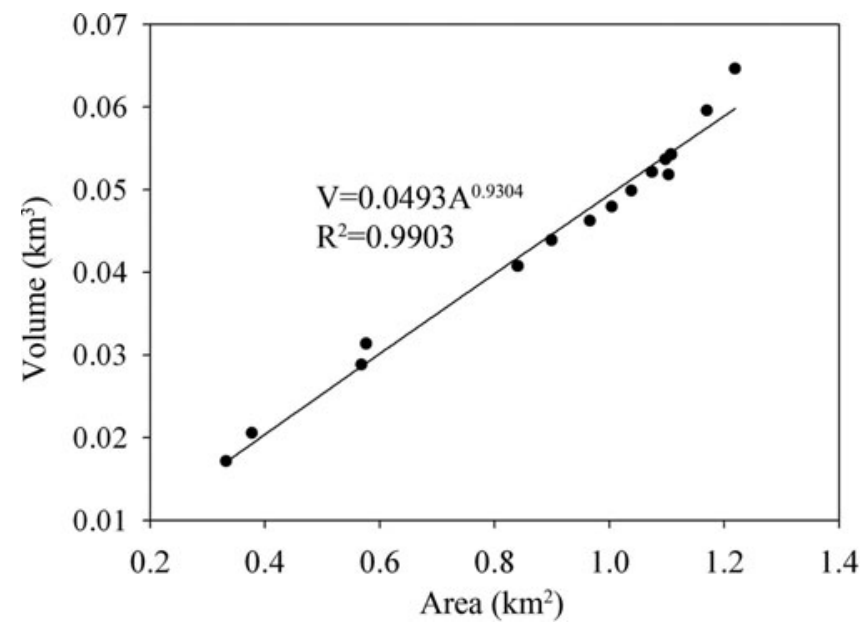

Fig. 8. Relationship between volume and area of Longbasaba lake for the period 1977-2009.

regression between the volume and area of Longbasaba lake is

$$
V=0.0493 \times A^{0.9304}\left(n=15, \quad R^{2}=0.9903\right)
$$

where $V$ is the volume $\left(\mathrm{km}^{3}\right), A$ is the area $\left(\mathrm{km}^{2}\right), n$ is the number of samples and $R^{2}$ is the coefficient of determination.

By using Eqn (3) and the formula suggested by Huggel and others (2002), we calculated the volumes of the moraine-dammed lakes in the Himalaya, for which we know storage capacities. The results indicate that the estimates using Eqn (3) are in good agreement with the observations, with the exception of lower Barun lake (Table 2). For lower Barun lake, the error ((calculated valuemeasured value)/measured value) was almost $40 \%$. A likely explanation for this is that lower Barun lake is a supraglacial lake, not a moraine-dammed lake (Mool and others, 2001). This, to some extent, also indicates that the storage capacity of moraine-dammed lakes is greater than that of supraglacial lakes. In addition, compared to the estimates using the formula suggested by Huggel and others (2004), the error using Eqn (3) was smaller. This suggests that the relation shown in Eqn (3) can produce more reliable estimates of the volume of moraine-dammed lakes in the Himalaya than the relation of Huggel and others (2004).

\section{CONCLUSION}

In this study, we have modeled the basin morphology of Longbasaba lake and analyzed changes, mainly variations in length and area during 1977-2009. The basin bottom of the lake is relatively flat and its flanks are steep. In 2009, the average depth of the lake was $48 \pm 2 \mathrm{~m}$, with a maximum value of $102 \pm 2 \mathrm{~m}$. During recent decades, the lake has shown a considerable increase in length and area, and especially since 2000 it has exhibited a drastic expansion. We estimated the storage capacity of the lake using the water depth together with geographical information techniques including GPS, remote sensing and GIS. The lake volume was $0.064 \pm 0.002 \mathrm{~km}^{3}$ in 2009 . Using the estimates of area and storage capacity in different periods, we established a regression equation relating lake volume and area. Analysis of the volumes of measured moraine-dammed lakes in the Himalayan region shows that our formula performs better than that proposed by Huggel and others (2002). That is, our equation provides a relatively accurate method for calculating volumes of unmeasured morainedammed lakes in the Himalayan region.

\section{ACKNOWLEDGEMENTS}

This work was funded by the National Natural Science Foundation of China (No. 41071044), the Knowledge Innovation Project of the Chinese Academy of Sciences (CAS; No. KZCX2-YW-Q03-04), the National Basic Work Program of Chinese MST (No. 2006FY110200), the Program of Enhancing Young Teachers' Scientific Research Ability of Northwest Normal University (NWNU-LKQN-1035), the Natural Science Foundation for Post-doctoral Scientists of China (20100480731) and the Fund of the State Key Laboratory of Cryosphere Science (2010-05). We gratefully acknowledge Xiaofeng Deng, Haidong Han, Zhen Wu and Yinsong Zhang, from the Cold and Arid Regions Environmental and Engineering Research Institute of CAS, who gave us great help in the water depth measurement of Longbasaba lake. We thank two anonymous reviewers and the scientific editor, B. Kulessa, for helpful comments and suggestions. We also thank Roger J. Braithwaite, Qiao Liu and Yong Zhang for helping to polish the English.

Table 2. Comparison of measured and calculated lake volumes for Himalayan moraine-dammed glacial lakes

\begin{tabular}{|c|c|c|c|c|c|c|}
\hline \multirow[t]{3}{*}{ Moraine-dammed lake } & \multirow{3}{*}{$\begin{array}{l}\text { Area } \\
\mathrm{km}^{2}\end{array}$} & \multirow{3}{*}{$\begin{array}{l}\text { Measured volume } \\
\qquad 10^{6} \mathrm{~m}^{3}\end{array}$} & \multicolumn{2}{|c|}{ Equation (3) } & \multicolumn{2}{|c|}{ Formula proposed by Huggel and others (2004) } \\
\hline & & & Calculated volume & Error & Calculated volume & Error \\
\hline & & & $10^{6} \mathrm{~m}^{3}$ & $\%$ & $10^{6} \mathrm{~m}^{3}$ & $\%$ \\
\hline Raphstreng Tsho* & 1.380 & 66.83 & 66.53 & -0.46 & 54.41 & -18.58 \\
\hline Tsho Rolpa ${ }^{\dagger}$ & 1.390 & 76.60 & 66.97 & -12.57 & 54.97 & -28.24 \\
\hline $\operatorname{Imja} \mathrm{a}^{\S}$ & 0.600 & 28.00 & 30.65 & 9.47 & 16.67 & -40.46 \\
\hline Gelhaipuco $^{\dagger}$ & 0.548 & 25.45 & 28.17 & 10.69 & 14.66 & -42.40 \\
\hline Tam Pokhari ${ }^{\dagger}$ & 0.470 & 21.25 & 24.42 & 14.92 & 11.79 & -44.52 \\
\hline Lower Barun ${ }^{\dagger}$ & 0.780 & 28.00 & 39.12 & 39.73 & 24.20 & -13.57 \\
\hline
\end{tabular}

Note: Symbols indicate consistency with published estimates in the literature: *Bhargava (1995); ${ }^{\dagger}$ Mool and others (2001); ${ }^{\star}$ Mool (1995); ${ }^{\circledR}$ Yamada and Sharma (1993). 


\section{REFERENCES}

Awal R, Nakagawa H, Fujita M, Kaiwake K, Baba Y and Zhang H (2010) Experimental study on glacial lake outburst floods due to waves overtopping and erosion of moraine dam. Ann. Disast. Prev. Res. Inst., 53(B), 583-594

Bajracharya SR and Mool P (2009) Glaciers, glacial lakes and glacial lake outburst floods in the Mount Everest region, Nepal. Ann. Glaciol., 50(53), 81-86 (doi: 10.3189/172756410790595895)

Bajracharya SR, Mool PK and Shrestha B (2007) Impact of climate change on Himalayan glaciers and glacial lakes: case studies on GLOF and associated hazards in Nepal and Bhutan. International Centre for Integrated Mountain Development and United Nations Environment Programme Regional Office, Asia and the Pacific, Kathmandu (ICIMOD Publication 169)

Benn DI, Warren CW and Mottram RH (2007) Calving processes and the dynamics of calving glaciers. Earth-Sci. Rev., 82(3-4), 143-179 (doi: 10.1016/j.earscirev.2007.02.002)

Bhargava ON (1995) Geology, environmental hazards and remedial measures of the Lunana area, Gasa Dzongkhag: report of 1995 Indo-Bhutan Expedition. Geological Survey of India, Kolkata

Carrivick JL (2010) Dam break-outburst flood propagation and transient hydraulics: a geosciences perspective. J. Hydrol., 380(3-4), 338-355

Che T, Jin R, Li X and Wu L-Z (2004) Glacial lakes variation and the potentially dangerous glacial lakes in the Pumqu Basin of Tibet during the last two decades. J. Glaciol. Geocryol., 26(4), $397-$ 402 [in Chinese with English summary]

Chen X, Cui P, Yang Z and Qi Y (2005) Changes in glaciers and glacier lakes in Boiqu River Basin, Middle Himalayas during last 15 years. J. Glaciol. Geocryol., 27(6), 793-800 [in Chinese with English summary]

Chen X, Cui P, Yang Z and Qi Y (2007) Risk assessment of glacial lake outburst in the Poiqu river basin of Tibet Autonomous Region. J. Glaciol. Geocryol., 29(4), 509-516 [in Chinese with English summary]

Chen X, Lu J, Cai X, Li H and Yin S (2008) Geomatics-based method research on capacity calculation of quake lake. Int. J. Remote Sens., 12(6), 885-892

Clague JJ and Evans SG (2000) A review of catastrophic drainage of moraine-dammed lakes in British Columbia. Quat. Sci. Rev., 19(17-18), 1763-1783

Ding $Y$ and Liu J (1992) Glacier lake outburst flood disasters in China. Ann. Glaciol., 16, 180-184

Evans SG (1986) The maximum discharge of outburst floods caused by breaching of man-made and natural dams. Can. Geotech. J., 23(3), 385-387

Fujita K, Suzuki R, Nuimura T and Sakai A (2008) Performance of ASTER and SRTM DEMs, and their potential for assessing glacial lakes in the Lunana region, Bhutan Himalaya. J. Glaciol., 54(185), 220-228 (doi: 10.3189/002214308784886162)

Gardelle J, Arnaud Y and Berthier E (2011) Contrasted evolution of glacial lakes along the Hindu Kush Himalaya mountain range between 1990 and 2009. Global Planet. Change, 75(1-2), 47-55 (doi: 10.1016/j.gloplacha.2010.10.003)

Haeberli W and 7 others (2004) The Kolka-Karmadon rock/ice slide of 20 September 2002: an extraordinary event of historical dimensions in North Ossetia, Russian Caucasus. J. Glaciol., 50(171), 533-546 (doi: 10.3189/172756504781829710)

Hall DK, Bayr KJ, Schöner W, Bindschadler RA and Chien JYL (2003) Consideration of the errors inherent in mapping historical glacier positions in Austria from ground and space (1893-2001). Remote Sens. Environ., 86(4), 566-577

He Y, Ma D, Cui P and Chen R (2002) Debris flows along the China-Nepal Highway. Acta Geogr. Sinica, 57(3), 275-283

Huggel C, Kääb A, Haeberli W, Teysseire Pand Paul F (2002) Remote sensing based assessment of hazards from glacier lake outbursts: a case study in the Swiss Alps. Can. Geotech. J., 39(2), 316-330

Huggel C, Haeberli W, Kääb A, Bieri D and Richardson S (2004) An assessment procedure for glacial hazards in the Swiss Alps. Can. Geotech. J., 41(6), 1068-1083
International Centre for Integrated Mountain Development (IClMOD) (2007) Inventory of glaciers, glacial lakes and identification of potential Glacial Lake Outburst Flood (GLOFs) affected by global warming in the mountains of Himalayan Region. International Centre for Integrated Mountain Development, Kathmandu

Komori J (2008) Recent expansions of glacial lakes in the Bhutan Himalayas. Quat. Int., 184(1), 177-186 (doi: 10.1016/ j.quaint.2007.09.012)

Li C and Zhang Y (2008) Consideration on disaster relief of Pida lake and Longbasaba lake in Tibet. China Water Res., 6, 32-34 [in Chinese with English summary]

Li Z and 12 others (2011) Climate and glacier change in southwestern China during the past several decades. Environ. Res. Lett., 6(4), 045404 (doi: 10.1088/1748-9326/6/ 4/045404)

Liu C and Sharma CK eds. (1988) Report on first expedition to glaciers and glacier lakes in the Pumqu (Arun) and Poiqu (BhoteSun Koshi) river basins, Xizang (Tibet), China. Science Press, Beijing

Lu A, Yao T, Wang L, Liu S and Guo Z (2005) Study on the fluctuations of typical glaciers and lakes in the Tibetan Plateau using remote sensing. J. Glaciol. Geocryol., 27(6), 783-792 [in Chinese with English summary]

Mool PK (1995) Glacier lake outburst floods in Nepal. J. Nepal Geol. Soc., 11, 273-280

Mool PK, Bajracharya SR and Joshi SP (2001) Inventory of glaciers, glacial lakes and glacial lake outburst floods, Nepal. International Centre for Integrated Mountain Development, Kathmandu

Ng F, Liu S, Mavlyudov B and Wang Y (2007) Climatic control on the peak discharge of glacier outburst floods. Geophys. Res. Lett., 34(21), L21503 (doi: 10.1029/2007GL031426)

Otero J, Navarro FJ, Martin C, Cuadrado ML and Corcuera MI (2010) A three-dimensional calving model: numerical experiments on Johnsons Glacier, Livingston Island, Antarctica. J. Glaciol., 56(196), 200-214 (doi: 10.3189/002214310791968539)

Pu J, Yao T, Wang N, Su Z and Seng Y (2004) Fluctuations of the glaciers on the Qinghai-Tibetan Plateau during the past century. J. Glaciol. Geocryol., 26(5), 517-522 [in Chinese with English summary]

Reynolds J (1998) Managing the risks of glacial flooding at hydro plants. Hydro Rev. Worldw., 6(2), 2-6

Richardson SD and Reynolds JM (2000) An overview of glacial hazards in the Himalayas. Quat. Int., 65/66(1), 31-47

Sakai A, Fujita K and Yamada T (2005) Expansion of the Imja glacier lake in the east Nepal Himalaya. In Mavlyudov BR ed. Glacier caves and glacial kerst in high mountains and polar regions. Institute of Geography, Russian Academy of Sciences, 74-79

Sakai A, Nishimura K, Kadota T and Takeuchi N (2009) Onset of calving at supraglacial lakes on debris-covered glaciers of the Nepal Himalaya. J. Glaciol., 55(193), 909-917 (doi: 10.3189/ $002214309790152555)$

Sharma KF, Sakai A, Nuimura T, Yamaguchi S and Sharma RR (2009) Recent changes in Imja Glacial Lake and its damming moraine in the Nepal Himalaya revealed by in situ surveys and multi-temporal ASTER imagery. Environ. Res. Lett., 4(4), 045205 (doi: 10.1088/1748-9326/4/4/045205)

Shi W, Yang C, You G and Jin M (1991) The measurement of reserve of glacier block lake on the upper stream of Yerqiang river and the calculation of its maximum flood. Arid Land Geogr., 14(4), 31-35

Shi Y and Ren J (1990) Glacier recession and lake shrinkage indicating a climatic warming and drying trend in central Asia. Ann. Glaciol., 14, 261-265

Shrestha AB, Eriksson M, Mool P, Ghimire P, Mishra B and Khanal MR (2010) Glacial lake outburst flood risk assessment of Sun Koshi basin, Nepal. Geomatics, Natur. Hazards Risks, 1(2), 157-169 
Singh P and Bengtsson L (2005) Impact of warmer climate on melt and evaporation for the rainfed, snowfed and glacierfed basins in the Himalayan region. J. Hydrol., 300, 140-154

Wang X and Liu SY (2007) An overview of researches on morainedammed lake outburst flood hazards. J. Glaciol. Geocryol., 29(4), 626-635

Wang X, Liu SY, Guo WQ and Xu JL (2008) Assessment and simulation of glacier lake outburst floods for Longbasaba and Pida lakes, China. Mt. Res. Dev., 28(3-4), 310-317

Wang X, Liu S, Yao X, Guo W, Yu P and Xu J (2010) Glacier lake investigation and inventory in the Chinese Himalayas based on the remote sensing data. Acta Geogr. Sinica, 65(1), 29-36

Williams RS, Jr, Hall DK and Chien JYL (1997) Comparison of satellite-derived with ground-based measurements of the fluctuations of the margins of Vatnajökull, Iceland, 1973-92. Ann. Glaciol., 24, 72-80

$\mathrm{Xu}$ D and Feng Q (1989) Dangerous glacial lake and outburst features in Xizang Himalayas. Acta Geogr. Sinica, 44(3), 343-352
Yamada T (1998) Glacier lake and its outburst flood in the Nepal Himalaya. Data Center for Glacier Research, Japanese Society of Snow and Ice, Tokyo

Yamada T and Sharma CK (1993) Glacier lakes and outburst floods in the Nepal Himalaya. IAHS Publ. 218 (Symposium at Kathmandu 1992 - Snow and Glacier Hydrology), 319-330

Yang X and 6 others (2006) Climate change in Mt. Qomolangma region in China during the last 34 years. Acta Geogr. Sinica, 61(7), 687-696

Yao T and 7 others (2010) Glacial distribution and mass balance in the Yarlung Zangbo River and its influence on lakes. Chinese Sci. Bull., 55(20), 2072-2078 (doi: 10.1007/s11434010-3213-5)

Zhang R, Fang H, Zhao F and Zeng F (2010) Remote sensing survey of existing glaciers in Qinghai-Tibet Plateau. Remote Sens. Land Resour., 86, 45-48 [in Chinese with English summary]

Zheng D, Lin Z and Zhang X (2002) Progress in studies of Tibetan Plateau and global environment change. Earth Sci. Frontiers, 9(1), 95-102 [in Chinese with English summary]

MS received 12 March 2011 and accepted in revised form 22 January 2012 